\title{
Seasonal Pattern of Hand Foot and Mouth Disease in an Outpatient Clinic of a Tertiary Care Pediatric Hospital, Dhaka
}

\author{
M Hussain ${ }^{1}$, M N Amin ${ }^{2}$, M R Islam ${ }^{3}$
}

Abstract

Background : Hand, foot and mouth disease (HFMD) is a contagious disease of children, occurs primarily under five years of age, characterized by a history of brief febrile illness and a typical skin rash over hands and feet with or without sores in mouth, caused usually by Coxsackie virus A16 viruses. It is mainly the disease of tropical and subtropical countries and bears a complex-relation with meteorological variables like temperature, rainfall and relative humidity, although no study has yet been done in Bangladesh to explain the complex relationship of the disease with these variables.

Objective : This study sought to describe the occurrence of HFMD and its association with meteorological factors in Dhaka city.

Methods : The present cross-sectional study collected data of 231 HFMD cases from the records of the daily register of Out-patient Department of Dhaka Shishu Hospital, Dhaka between January 2018 to December 2019. According to the study protocol a child was identified as having HFMD who had a history of brief febrile illness accompanied by a typical skin rash with or without mouth ulcers. Total numbers of cases treated monthly at OPD during the period were also recorded. Meteorological data were provided by Bangladesh Meteorological Department, which among others, included monthly average temperature, relative humidity and amount of rainfall. While the outcome variable was monthly number of HFMD cases, the predictive variables were average temperature, humidity and rainfall during the study period.

Results : Majority (85.3\%) children in the present study was $<5$ years old. A male preponderance was observed in the series $(60 \%)$ with male to female ratio being $3: 2$. A clustering of HFMD cases was observed to occur between June to October when monthly average temperature, total rainfall and humidity all were at their maximum compared to those found between November to April. The clustering of cases was more intense in the year 2019 than that in the year 2018. During the period average monthly temperature was $29.2^{\circ} \mathrm{C}$, average rainfall was $62.6 \%(238 \mathrm{~mm})$ of the total annual precipitation and mean relative humidity was $79 \%$. The proportion of HFMD cases out of total cases treated during the period was $2.2 \%$ in 2018 and was $4.1 \%$ in 2019, which in the dry season (November to April) was $0.4 \%$ and $0.5 \%$ in 2018 and 2019 respectively.

\section{Dr. Mahfuza Hussain Consultant (Dermatology) Dhaka Shisu Hospital, Dhaka \\ ${ }^{2}$ Dr. Md. Nurul Amin Associate Professor (Research) \& Executive Editor, Ibrahim Cardiac Medical Journal, Ibrahim Cardiac Hospital \& Research Institute Shahbag, Dhaka}

${ }^{3}$ Dr. Md. Rafiqul Islam Resident Medical Officer Dhaka Shisu Hospital, Dhaka

Correspondence Dr. Mahfuza Hussain Consultant (Dermatology) Dhaka Shisu Hospital, Dhaka Email : mafihag@gmail.com

Conclusions : The study concluded that majority of the HFMD cases occur under five years of age and boys are more likely to have the infection than the girls. A seasonality of HFMD occurrence is observed with a higher number of cases occurring in the monsoon season and fewer cases in the dry season.Clustering of HFMD cases occur between May to October when monthly average temperature, total rainfall and humidity all are at peak compared to those in November to April of the year.

Key words : Hand foot and mouth disease, temperature, rainfall, relative humidity etc.

DOI: https://doi.org/10.3329/nimcj.v11i2.54060

Northern International Medical College Journal Vol. 11 No. 2 January 2020, Page 453-457

\section{Introduction}

Hand Foot and Mouth Disease (HFMD) $)^{1}$ is a contagious disease of children usually under five years of age characterized by sores in mouth and rashes over hands and feet caused by viruses. Most patients have mild symptoms, including fever and rashes and herpes in the hands, feet and mouth. A few cases may present with meningitis, encephalitis, pulmonary oedema, and circulatory disorders and even die of the diseases. ${ }^{2}$ Infection occurs through direct contact or droplets, via respiratory secretions such as saliva, sputum, and nasal discharge, contact with blister fluid of infected individuals 
and from other excretory materials of an infected person. ${ }^{3}$ The disease is primarily caused by Coxsackievirus $A 16^{4}$ followed by enterovirus 71, though other strains of coxsackie virus and enterovirus may also cause the disease. ${ }^{5}$ There are reports of outbreaks in HFMD over the past several years in the tropical and subtropical regions of the world and the situation may worsen in future due to climate change and poor health care surveillance. ${ }^{6}$

Seasonal variability in incidence of HFMD is noted in different countries. ${ }^{7-11}$ Outbreaks of this disease in China, Singapore, Malaysia and Taiwan usually peak in the late spring/early summer, along with a second small peak in late autumn/early winter. In Japan ${ }^{12}$ its peak is detected during the summer months. However, in Finland most HFMD cases were reported in autumn. ${ }^{13}$ Peak of HFMD incidence in children in China was from May to July which might relate to the survival ability of enteroviruses. ${ }^{14}$ In Vietnam HFMD increased $7 \%$ for $1^{\circ} \mathrm{C}$ increase in monthly temperature above $26^{\circ} \mathrm{C}$ and $1 \%$ increase in monthly humidity above $76 \% .{ }^{15}$ In the same study in Vietnam, HFMD decreased $3.1 \%$ with $1 \mathrm{~mm}$ increase in monthly cumulative rainfalls.

Though a study done in northern Bangladesh ${ }^{16}$ showed May and September-October as peak season for HFMD but meteorological variables affecting incidence of HFMD is not known in Dhaka, Bangladesh. This study was done to see the impact of meteorological factors like temperature, rainfall and humidity on the incidence of HFMD in Dhaka city.

\section{Methods}

\section{Topographical feature of the study area:}

The climate of Bangladesh is subtropical in the center-north and tropical in the south, with a pleasantly warm and sunny winter from November to February, a short hot spring between March and May, and a long rainy season from June to October due to the summer monsoon. The study was conducted in the capital city, Dhaka, which is located in central Bangladesh at $23^{\circ} 42^{\prime} \mathrm{N}$ $90^{\circ} 22^{\prime} \mathrm{E}$, on the eastern banks of the Buriganga river.

\section{Meteorological condition of the study area:}

Dhaka experiences a hot, wet and humid tropical climate. Under the Köppen climate classification, Dhaka has a tropical wet and dry climate. The city has a distinct monsoonal season, with an annual average temperature of $25^{\circ} \mathrm{C}\left(77^{\circ} \mathrm{F}\right)$ and monthly means varying between $18^{\circ} \mathrm{C}\left(64^{\circ} \mathrm{F}\right)$ in January and $29^{\circ} \mathrm{C}\left(84^{\circ} \mathrm{F}\right)$ in August. Approximately $87 \%$ of the annual average rainfall of 2,123 millimeters (83.6 inches) occurs between May and October. The wettest month for Dhaka is July with an average of $367.9 \mathrm{~mm}$ of precipitation falling while the driest month is December with $8.9 \mathrm{~mm}$ falling. ${ }^{17}$

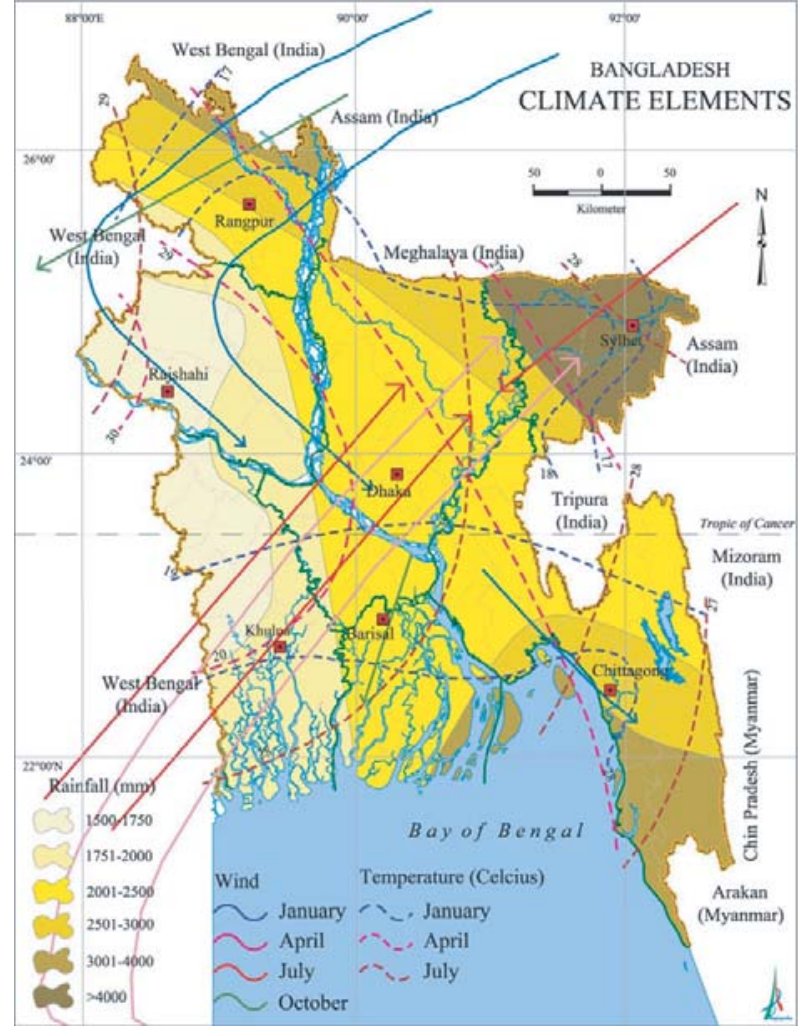

Fig. 1: Map of Bangladesh showing Climate Elements

(Source: Climate-Bangladesh. National Encyclopedia, Bangladesh, Available at: en.banglapedia.org)

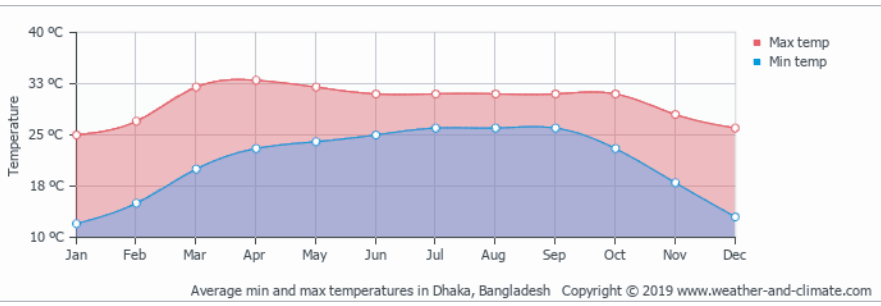

Fig. II : Monthly average minimum maximum temperatures of Dhaka, Bangladesh

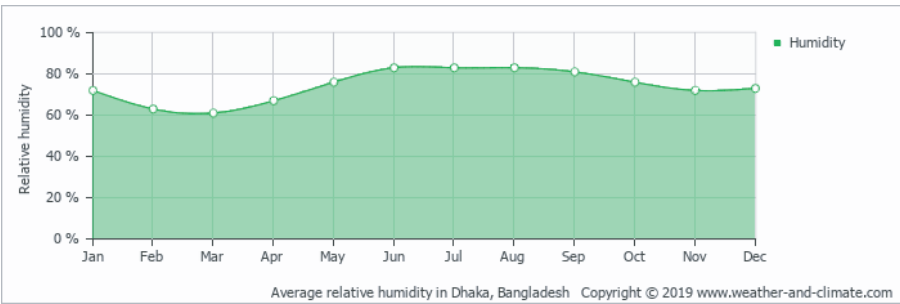

Fig. III : Average relative humidity (RH)of Dhaka, Bangladesh

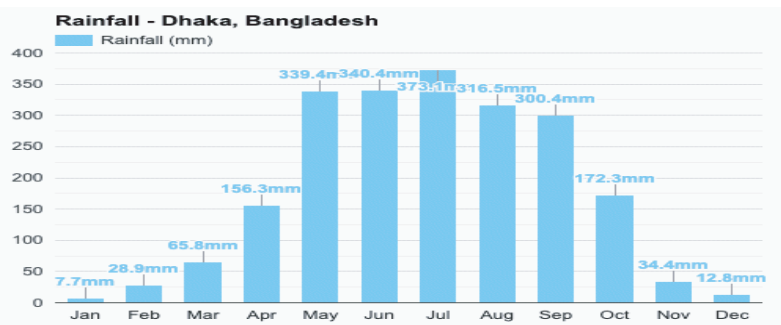

Fig. IV : Monthly average rainfall in Dhaka, Bangladesh 


\section{Data collection}

The data of HFMD cases were collected from the Out-patient Department of Dhaka Shishu Hospital, a Tertiary Pediatric Hospital in Dhaka City over a period of 2 years from January 2018 to December 19. According to the study protocol (based on WHO recommendations $)^{18}$ a child was diagnosed as having HFMD who had a history of brief febrile illness accompanied by a typical skin rash in hand, foot and mouth with or without mouth ulcers. Once identified, a patient was treated either at the OPD setting or was admitted In-patient, depending on the severity of the condition. Total numbers of HFMD cases were recorded monthly during the study period from 2018 to2019. Meteorological data were provided by Bangladesh Meteorological Department, under Ministry of Defense of the Government of Bangladesh, which among others, included monthly average temperature $\left({ }^{\circ} \mathrm{C}\right)$, relative humidity $(\%)$ and amount of rainfall $(\mathrm{mm})$. While the outcome variable was the monthly number of HFMD cases, the predictive variables were average temperature, humidity and rainfall during the study period. Data were analyzed using SPSS (Statistical Package for Social Sciences), version 25.0. The test statistics used to analyze the data were descriptive statistics. The qualitative data were expressed in frequency and corresponding percentage and the quantitative data were presented as mean and standard deviation from the mean.

\section{Result}

Age distribution of the selected study children shows that nearly $30 \%$ of the patients were <1-year-old, $56.3 \% 1-5$ years old and $14.7 \% 5$ or $>5$ years old with median age of the patients being $1.5 \pm 0.2$ years. Approximately $60 \%$ of the children were male with male to female ratio being 3:2 (Table I).

Table I : Distribution of children by their demographic characteristics ( $n=231)$

$\begin{array}{lcc}\begin{array}{l}\text { Demographics } \\ \text { Age* (years) }\end{array} & \text { Frequency } & \text { Percentage } \\ <1 & 67 & \\ 1-5 & 130 & 29.0 \\ \geq 5 & 34 & 56.3 \\ \text { Sex } & & 14.7 \\ \text { Male } & 137 & \\ \text { Female } & 94 & 59.3 \\ \end{array}$

$*$ Median age $=1.5 \pm 0.2$ years; range $=(0.42-15)$ years

In our study there are clustering of HFMD cases between June to October (rainy season) when monthly average temperature, total rainfall and humidity all were peak compared to those in November to April (dry season) of the year. The clustering of cases was more intense in the year 2019 than that in the year 2018 as is evidenced from the graph of the time distribution of the HFMD cases. During the period average monthly temperature was $29.2^{\circ} \mathrm{C}$, average rainfall was $62.6 \%$ of the total annual precipitation and mean relative humidity was $78.6 \%$. The proportion of HFMD cases out of total cases treated during the period was $2 \%$ in 2018 and was $4.1 \%$ in 2019, which in the dry season (November to April) was $0.4 \%$ and $0.5 \%$ in 2018 and 2019 respectively (Table II, III and Fig. 5).

\begin{tabular}{|c|c|c|c|c|}
\hline Year 2018 & $\begin{array}{l}\text { Number of } \\
\text { Cases }\end{array}$ & $\begin{array}{l}\text { Monthly average } \\
\text { temperature }\left({ }^{\circ} \mathrm{C}\right)\end{array}$ & $\begin{array}{l}\text { Monthly total } \\
\text { rainfall (mm) }\end{array}$ & $\begin{array}{l}\text { Monthly average } \\
\text { relative humidity (\%) }\end{array}$ \\
\hline January & 00 & 17.5 & 0.0 & 69.4 \\
\hline February & 00 & 23.2 & 20.0 & 62.1 \\
\hline March & 00 & 27.3 & 3.0 & 60.2 \\
\hline April & 00 & 27.3 & 309.0 & 70.0 \\
\hline May & 02 & 27.6 & 392.0 & 79.6 \\
\hline June & 06 & 29.4 & 366.0 & 82.0 \\
\hline July & 10 & 29.3 & 354.0 & 82.2 \\
\hline August & 12 & 29.8 & 141.0 & 78.5 \\
\hline September & 17 & 29.8 & 76.0 & 77.7 \\
\hline October & 18 & 27.3 & 45.0 & 72.7 \\
\hline November & 06 & 24.2 & 13.0 & 69.0 \\
\hline December & 03 & 20.3 & 13.0 & 66.5 \\
\hline
\end{tabular}

Table III : Seasonal variation of HFMD cases in 2019 stratified by month Year 2019 Number of Monthly average Monthly total Monthly average Cases temperature $\left({ }^{\circ} \mathrm{C}\right)$ rainfall $(\mathrm{mm})$ relative humidity $(\%)$

$\begin{array}{lllcl}\text { January } & 00 & 20.2 & 1.0 & 60.3 \\ \text { February } & 00 & 22.0 & 115.0 & 63.6 \\ \text { March } & 00 & 26.0 & 39.0 & 62.1 \\ \text { April } & 00 & 28.3 & 212.0 & 70.2 \\ \text { May } & 00 & 29.8 & 231.0 & 73.6 \\ \text { June } & 04 & 29.9 & 242.0 & 79.4 \\ \text { July } & 14 & 29.3 & 383.0 & 82.7 \\ \text { August } & 26 & 29.9 & 223.0 & 79.4 \\ \text { September } & 53 & 29.1 & 161.0 & 81.0 \\ \text { October } & 36 & 27.6 & 188.0 & 78.6 \\ \text { November } & 12 & 20.2 & 1.0 & 60.3 \\ \text { December } & 02 & 22.0 & 115.0 & 63.6\end{array}$

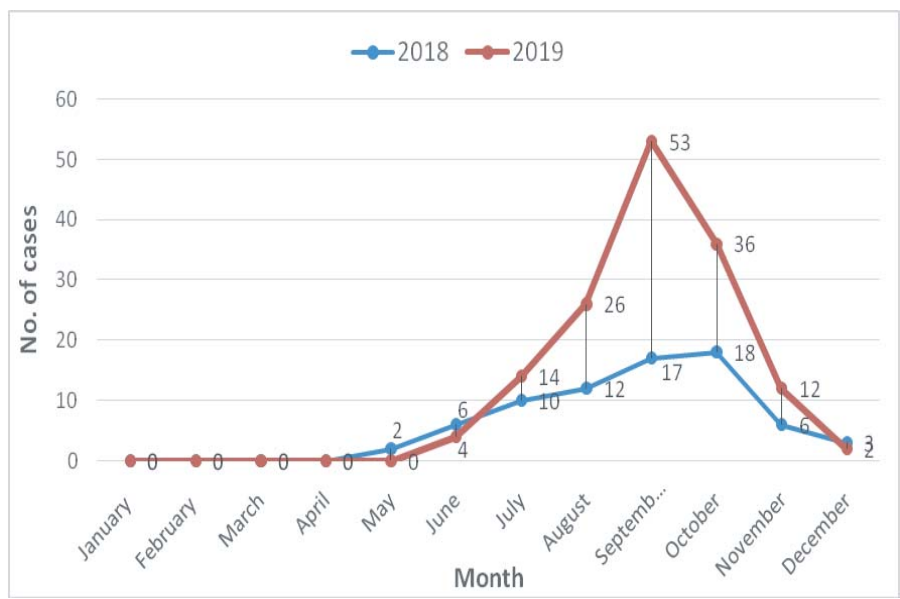

Fig. V : HFMD cases presented in 2018 through 2019 stratified by months 
Table IV. Proportional HFMD morbidity out of total morbidity in rain and dry seasons

\begin{tabular}{|c|c|c|c|c|c|c|c|}
\hline Year & $\begin{array}{l}\text { (Total HFMD cases } \\
\text { in rainy } \\
\text { season)/(Total no. } \\
\text { of cases in rainy } \\
\text { season) }\end{array}$ & $\begin{array}{l}\text { Proportion of } \\
\text { HFMD morbidity } \\
\text { out of total } \\
\text { morbidity in rainy } \\
\text { season }\end{array}$ & $\begin{array}{l}\text { (Total HFMD cases } \\
\text { in dry } \\
\text { season)/(Total no. } \\
\text { of cases in dry } \\
\text { season) }\end{array}$ & $\begin{array}{l}\text { Proportion of } \\
\text { HFMD morbidity } \\
\text { out of total } \\
\text { morbidity in dry } \\
\text { season }\end{array}$ & $\begin{array}{l}\text { Monthly } \\
\text { average temp. } \\
\text { (C) in } \\
\text { rainy/dry } \\
\text { season }\end{array}$ & $\begin{array}{l}\text { Monthly total } \\
\text { rainfall }(\mathrm{mm}) \\
\text { in rainy/dry } \\
\text { season }\end{array}$ & $\begin{array}{l}\text { average } \\
\text { relative } \\
\text { humidity (\%) } \\
\text { in rainy/dry } \\
\text { season }\end{array}$ \\
\hline 2018 & $65 / 2852$ & $2.2 \%$ & $9 / 2006$ & $0.4 \%$ & $28.9 / 23.3$ & $229 / 59.6$ & $78.8 / 66.2$ \\
\hline 2019 & $133 / 3218$ & $4.1 \%$ & $14 / 2694$ & $0.5 \%$ & $29.2 / 23.1$ & $238 / 80.5$ & $79.1 / 63.3$ \\
\hline
\end{tabular}

\section{Discussion}

The present study is, by far, the first study examining the relationship between climatic variables and HFMD occurrence in Bangladesh. In this study majority (85.3\%) of children was $<5$ years old with a male predominance $(60 \%)$ which is quite consistent with the findings of a large-scale South Korean study (which incorporated 7 years data from 2011 to 2017), where HFMD primarily occurred in children younger than 4 years of age with greatest proportion of cases being found at ages 1 (39.2\%) and $2(25.7 \%){ }^{19}$

Our study demonstrated a seasonal pattern of HFMD occurrence with a higher number of cases occurring in the monsoon season and a few cases in dry season. A recent study conducted in Viet Nam showed that the number of HFMD cases increased during the rainy season and the number is determined by meteorological variables. ${ }^{20}$

An increased risk of HFMD was associated with higher average temperature (risk ratio and 95\% confidence interval: 1.06; 1.03-1.08 per $1{ }^{\circ} \mathrm{C}$ increase), higher rainfall $(1.19 ; 1.14-1.24$ per $200 \mathrm{~mm}$ increase) and longer sunshine duration (1.14; 1.07-1.22 per 60 hours increase), while the risk of HFMD was inversely associated with wind speed $(0.77 ; 0.73-0.81$ per $1 \mathrm{~m} / \mathrm{s}$ increase). ${ }^{20} \mathrm{~A}$ previous study in Viet Nam also reported consistent result. ${ }^{21}$ However, the transmission rate of HFMD in three provinces of China explains the complex transmission dynamics. Meteorological factors cannot solely explain the seasonality in HFMD transmission in mainland China; the Chinese Spring Festival period, population flux and (or) school terms explain most of the transmission rate seasonality of HFMD and they act as driving forces for HFMD transmission rate seasonality in different time periods of the year. ${ }^{22}$ The Chinese Spring Festival period dominantly caused the dramatic increase of the HFMD transmission rate during February due to population flux and seasonal contact rate in population. ${ }^{23}$ Some other studies in China also did not support the association between rainfall and HFMD. ${ }^{23,24}$ However, the South Korean study clearly showed that incidence of HFMD tended to increase from May, peak between July and September and increase rapidly in 1 - to 2 -year cycles. ${ }^{19}$
HFMD has seasonality. In temperate regions, the number of patients who are infected with enteroviruses rises in summer. ${ }^{25,26}$ In subtropical and tropical regions, enteroviruses circulate throughout the year and elevate during the rainy season. Pham and associates ${ }^{20}$ found each $200 \mathrm{~mm}$ increase in rainfall to be associated with a $19 \%$ increased risk of HFMD onset. A possible explanation is that high rainfall makes soil moist, which may facilitate viral persistence and spreading. 27,28 Although, exact reasons for the relationship between climatic variables and HFMD are limited, meteorological factors like warm and moist weather could affect occurrences of infectious disease via survival and transmission of pathogens in the environment. Besides, population activities and behavior changes in different seasons may cause children vulnerable to acquire the infection. ${ }^{29,30}$

High temperatures could increase the growth of enteroviruses and also interfere with its inactivation. ${ }^{29,31}$ In agreement with some previous studies that humidity is associated with HFMD, ${ }^{23,26,32,33}$ the current study also observed an increasing trend of HFMD cases in the monsoon season when average relative humidity remains at its highest $(79 \%)$.

\section{Conclusion}

The study concluded that majority of the HFMD cases occur under five years of age and boys are more prone to acquire the infection than the girls. A seasonal pattern of HFMD occurrence is evident with a higher number of cases occurring in the monsoon season and a few cases in dry season.Clustering of HFMD cases occur between June to October when monthly average temperature, total rainfall and humidity all are at their peak compared to those in the dry season of the year. A largescale, multicenter study, with inclusion of other meteorological variables and human behavioral factors, is recommended to study seasonality and transmission dynamics of HFMD in Bangladesh. 


\section{References}

1. WHO: A guide to Clinical management \& public health response for Hand, Foot \& Mouth Disease. Sec. 5: Clinical Features \& case management. 2011; 19.

2. Li J, Wang J, Xu C, et al. Hand, foot, and mouth disease in mainland China before it was listed as category $C$ disease in May, 2008. Lancet Infect Dis. 2017;17(10): 1017-1018.

3. Abzug MJ. Nonpolio Enteroviruses In: Kliegman RM, ed. Nelson Textbook of Pediatrics, 18th ed. Philadelphia: Saunders, 2007. pp. 1350-1356.

4. Repass GL, Palmer WC, Stancampiano FF. Hand, foot, and mouth disease: Identifying and managing an acute viral syndrome. Cleve Clin J Med. 2014;81(9):537-43.

5. Ming KW, Tiffany B, Karen S, Jing J, Elizabeth CY, Yew TC, Ic CM, Peter H, Alex CR. The Epidemiology of Hand, Foot and Mouth Disease in Asia: A Systematic Review and Analysis. The Pediatric Infectious Disease Journal. 2016;35(10):e285-300.

6. Ma E, Lam T, Chan KC, Wong C, Chuang SK. Changing epidemiology of hand, foot, and mouth disease in Hong Kong, 2001-2009. Jpn J Infect Dis. 2010;63(6):422-426.

7. Onozuka $D$, Hashizume $M$. The influence of temperature and humidity on the incidence of hand, foot, and mouth disease in Japan. Sci Total Environ. 2011;410-411:119-125.

8. Ang LW, Koh BK, Chan KP, Chua LT, James L, Goh KT. Epidemiology and control of hand, foot and mouth disease in Singapore, 2001-2007. Ann Acad Med Singapore. 2009;38(2):106-112.

9. Chua KB, Kasri AR. Hand foot and mouth disease due to enterovirus 71 in Malaysia. Virol Sin. 2011;26(4):221-228.

10. Ho M, Chen ER, Hsu KH, Twu SJ, Chen KT, Tsai SF, Wang JR, Shih SR. An epidemic of enterovirus 71 infection in taiwan. Taiwan enterovirus epidemic working group. New Eng J Med. 1999;341(13):929-935.

11. Zhu Q, Hao Y, Ma J, Yu S, Wang Y. Surveillance of hand, foot, and mouth disease in mainland China (2008-2009). Biomed Environ Sci. 2011;24(4):349-356.

12. Fujimoto T, Iizuka S, Enomoto $M$, Abe K, Yamashita $K$, Hanaoka N, Okabe N, Yoshida $\mathrm{H}$, Yasui $Y$, Kobayashi M. Hand, foot, and mouth disease caused by coxsackievirus A6, Japan, 2011. Emerg Infect Dis. 2012;18(2):337-339.

13. Blomqvist $S$, Klemola P, Kaijalainen $S$, Paananen $A$, Simonen $M L$, Vuorinen $T$, Roivainen M. Co-circulation of coxsackieviruses A6 and A10 in hand, foot and mouth disease outbreak in Finland. J Clin Virol. 2010;48(1):49-54.

14. Clinical and epidemiological characteristics of adult hand, foot, and mouth disease in northern Zhejiang, China, May 2008 - November 2013 XinguangYin , Hui-xing Yi , Jin Shu, Xing-ju Wang , Xiao-jun Wu and Ling-hua Y. BMC Infectious Diseases 2014, 14:251 http://www.biomedcentral.com/ $1471-2334 / 14 / 251$

15. Phung D, Xuan H, Nguyen HLT, Manh C, Tran QD, Chu C. Spatiotemporal variation of hand-foot-mouth disease in relation to socioecological factors: $\mathrm{A}$ multiple-province analysis in Vietnam. Science of the Total Environment. 2018;610-611:983-991.

16. Khan MAH, Anwar KS, Muraduzzaman AKM, Mollah MAH, Alam SMAU, Islam KM, Hoque SA, Islam MN, Ali MA. Emerging Hand Foot Mouth Disease in Bangladeshi Children- First Report of Rapid Appraisal on Pocket Outbreak: Clinico-epidemiological Perspective Implicating Public Health Emergency [version 3; peer review: 2 approved]. F1000Research 2019, 7:1156 (https://doi.org/10.12688/f1000research.15170.3)
17. Weatherbase. Historical Weather for Dhaka, Bangladesh. weatherbase.com. Retrieved 15 December 2008.

18. A guide to clinical management and public health response for hand, foot and mouth disease HFMD). Geneva: World Health Organization; 2011. Available from: http://www.wpro.who.int/publications/docs/Guidance for the clinical management of HFMD. pdf DOI:10.21203/rs.2.17027/v1

19. L Xie, R Huang,H Wang, Z Xiao.Spatial-temporal mapping of hand, foot and mouth disease in relation to climate factors in Xinjiang, China from 2008 to2016;ORCiD: https://orcid.org/0000-0002-1033-0420 DOI:10.21203/rs.2. $17027 / v 1$

20. Pham HV, Phan UTN,Phamc ANQ. Meteorological factors associated with hand, foot and mouth disease in a Central Highlands province in Viet Nam: an ecological study. Western Pac Surveill Response J. 2019;10(4):18-23.

21. Van Tu P, Thao NTT, Perera D, Truong KH, Tien NTK, Thuong TC, et al. Epidemiologic and virologic investigation of hand, foot, and mouth disease, southern Vietnam, 2005. Emerg Infect Dis. 2007;13(11):1733-41.

22. Zhaocorresponding J, Hu X. The complex transmission seasonality of hand, foot, and mouth disease and its driving factors. BMC Infect Dis. 2019;19 521

23. Huang Y, Deng T, Yu S, Gu J, Huang C, Xiao G, et al. Effect of meteorological variables on the incidence of hand, foot, and mouth disease in children: a time-series analysis in Guangzhou, China. BMC Infect Dis. 2013;;13(1):134.

24. Li T, Yang Z, Di B, Wang M. Hand-foot-and-mouth disease and weather factors in Guangzhou, southern China. Epidemiol Infect. 2014;142(8): 1741-50.

25. van der Sanden S, Koopmans M, Uslu G, van der AvoortH; Dutch Working Group for Clinical Virology. Epidemiology of enterovirus 71 in the Netherlands, 1963 to 2008. J Clin Microbiol. 2009;47(9):2826-33.

26. Ma $E$, Lam T, Wong $C$, Chuang SK. Is hand, foot and mouth disease associated with meteorological parameters? Epidemiol Infect. 2010;138(12): 1779-88.

27. Wei J, Hansen A, Liu Q, Sun Y, Weinstein P, Bi P. The effect of meteorological variables on the transmission of hand, foot and mouth disease in four major cities of shanxi province, China: a time series data analysis (20092013). PLoSNegl Trop Dis. 2015;9(3):e0003572.

28. Rajtar B, Majek M, Pola $\square$ ski , Polz-Dacewicz M. Enteroviruses in water environment-a potential threat to public health. Ann Agric Environ Med. 2008;15(2):199-203.

29. Dong W, Li X, Yang P, Liao H, Wang X, Wang Q. The effects of weather factors on hand, foot and mouth disease in Beijing. Sci Rep. 2016;6(1):19247.

30. Kuhn K, Campbell-Lendrum D, Haines A, Cox J. Using climate to predict infectious disease epidemics. Geneva: World Health Organization; 2005. Available from: Available from https://www.who.int/globalchange/ publications/infectdiseases/

31. Yeager JG, O'Brien RT. Enterovirus inactivation in soil. Appl Environ Microbiol. 1979;38(4):694-701.

32. Chen $C$, Lin $H$, Li X, Lang $L$, Xiao $X$, Ding $P$, et al. Short-term effects of meteorological factors on children hand, foot and mouth disease in Guangzhou, China. Int J Biometeorol. 2014;58(7):1605-14.

33. Hu M, Li Z, Wang J, Jia L, Liao Y, Lai S, et al. Determinants of the incidence of hand, foot and mouth disease in China using geographically weighted regression models. PLoS One. 2012;7(6):e38978. 